\title{
Dividend Announcement and Ex-Dividend Effects on Stock Return
}

\author{
Dinh Bao Ngoc ${ }^{1} \&$ Nguyen Chi Cuong ${ }^{1}$ \\ ${ }^{1}$ Faculty of Finance, University of Economics, The University of Danang, Vietnam \\ Correspondence: Dinh Bao Ngoc, University of Economics, 71 Ngu Hanh Son St., Danang City, Vietnam. Tel: \\ 84-914-303-060. E-mail: ngocdb@due.edu.vn
}

Received: April 6, 2016

doi:10.5539/ijef.v8n7p207
Accepted: April 27, 2016

Online Published: June 25, 2016

URL: http://dx.doi.org/10.5539/ijef.v8n7p207

\begin{abstract}
We study the impact of dividend policy on the stock return by investigating reaction of the stock price on the dividend announcement date and the ex-dividend date. In order to achieve this goal, a sample comprising 1962 observations of dividend-related events from 432 listed companies in Vietnam during the period 2008 to 2015 is chosen to analyze and the event study methodology is used to estimate abnormal returns to the shares around the announcement date and the ex-dividend date. Our results clearly show that the effect of dividend announcement on the stock return is positive around the announcement date. In addition, the stock price moves up as long as the ex-dividend date approaches and then starts decreasing from this date onwards.
\end{abstract}

Keywords: dividend policy, announcement date, ex-dividend date, stock return, event study

\section{Introduction}

A dividend policy plays an important role in corporate finance since an optimal dividend policy is the aim of financial management to increase company value. Reaction of stock price to the dividend policy is a debate topic during the last several decades. In terms of the relation between the dividend policy and the firm value, there are two conflicted theories which are dividend irrelevance and dividend relevance. According to the dividend irrelevance theory developed by Miller and Modigliani (1961), there is no relation between the stock value and the dividend policy in the perfect world. However, the bird-in-the-hand theory presented by Linter (1956) and Gordon (1963) argues that shareholders prefer receiving dividend payments rather than uncertain capital gains in the future. The payment of dividend would create the value for the shareholders; therefore the dividend policy affects the firm value. In addition, there have been also several previous empirical researches about the relation between the dividend policy and the stock reactions to be conducted and they showed different results.

Taking account of these contradictions, in this research we analyze the influence of dividend announcement on the stock return of the firms in Vietnam which has not much been considered previously. Based on the investigation of the stock returns subsequent to these announcements, we are able to determine whether the effects of the dividend policy on balance create or reduce the firm value.

\section{Literature Review}

Dividend policy refers to "the practice that management follows in making dividend payout decisions or, in other words, the size and pattern of cash distributions over time to shareholders" (Lease et al., 2000). Study of the dividend policy has attracted considerable attention of finance scholars since the middle of the last century. They have attempted to explain corporate dividend behavior because the dividend seems to be an enigma in corporate finance. In fact, Black (1976) described it as a "puzzle" and Allen et al. (2000) concluded as "Although a number of theories have been put forward in the literature to explain their pervasive presence, dividends remain one of the thorniest puzzles in corporate finance".

The main contradictory approaches of dividends are summarized in two theories of the dividend policy which are the dividend irrelevance theory and the dividend relevance theory. Moreover, some of other arguments including the information content of dividends (signaling), the clientele effects, and the agency cost hypotheses are also used to explain corporate dividend behavior.

One of the most important theoretical studies about the relation between the dividend policy and the firm value was carried out by Miller and Modigiliani (M\&M) in 1961. In this research, they showed that under certain assumptions about perfect capital markets and rational investors, a firm's dividend policy does not affect its 
value, i.e., the dividend policy would be irrelevant. The value of companies is calculated based on the capitalized value of their future earnings and this is not affected by if the firms pay dividends or not. In other words, the firm value is determined by the income generated from the investment decisions of a firm. M\&M (1961) mentioned that the pre-existing dividend clientele effect hypothesis might play a role in the dividend policy under certain conditions. M\&M argued that these imperfections might cause investors to choose securities that reduce costs. M\&M supposed the tendency of investors to be attracted to a certain type of dividend-paying stocks a "dividend clientele effect".

There are also a few empirical studies, e.g., Black and Scholes (1974), Miller and Scholes (1978, 1982), Chen et al. (2002), Adefila et al. (2004), Uddin and Chowdhurry (2005) supporting for M\&M theory. However, the study conducted by Ball et al. (1979), Baker et al. (1985) and Baker and Powel (1999) criticized M\&M theory because this theory was proposed under unrealistic assumption.

An alternative view about the effect of the dividend policy on the firm value is that the dividends affect the firm value. The bird-in-the-hand theory of Linter (1956) and Gordon (1959) argued that in a world of uncertainty and imperfect information, dividends are valued differently to retained earnings (or capital gains). Shareholders prefer a higher current dividend payments rather than uncertain capital gains in the future because "a bird in the hand is worth more than two in the bush". Particularly, increasing dividend payments would be associated with increases in firm value. Indeed, a high dividend payout ratio would reduce the cost of capital leading to an increase of the firm value. The empirical studies which support the bird-in-the-hand theory are known as Bhattacharya (1979), Travlos et al. (2001), Baker et al. (2002), Mayers and Frank (2004), Dong et al. (2005) and Maditinos et al. (2007).

The asymmetric information between the managers and the shareholders is also a hypothesis for an inadequate dividend irrelevance hypothesis of M\&M. It is likely that the dividends have implicit information about a firm's prospects and convey this information to the market. This proposition has been considered as the "information content of dividends" or the "signaling hypothesis". The announcement of increased dividend is good news leading to higher share prices. On the other hand, the announcement of decreased dividend causes unfavourable prospects which tend to reduce share prices. More details about the dividend signaling models can be found in John and Williams (1985), and Miller and Rock (1985).

Several empirical studies examined the impact of the dividend policy on the share price volatility and exhibited results differently. Friend and Puckett (1964) and Basin (1989) found that there is a positive correlation between dividend and share price volatility. Nevertheless, the results obtained by Fama and French (1988) and Ohlson (1995) showed the negative relation. On the other hand, Allen and Rachim (1996) and Rashid and Rahman (2008) showed that there is no evidence about the impact of dividend yield on price volatility.

Regarding empirical studies about the impact of dividend announcement on the stock price, Scott and Keith (1996) supported the information content of dividend hypothesis by showing a significant impact on abnormal returns of the dividend announcement. Their study indicated that the dividend change announcement conveys information to the market phase. In addition, according to Aharony and Swary (1980), there is a strong impact between quarterly cash dividend and stockholders return since changes of cash dividends provide information about changes of firm's performance in the future. These results were consistent with the information content of dividends hypothesis.

However, Romon (2000) doubted the dividend clientele hypothesis. By examining the stock price reactions at the dividend announcement and that at the ex-dividend date, he found that around the dividend announcement date, the informational effect of dividend announcement depends on the firm dividend policy level. Around the ex-dividend dates, the dividend clientele effect seems to be significantly limited since the market knows the firm dividend policy level.

In 2007, by analyzing the ex-dividend stock price, Dasilas found that significant positive abnormal returns are observed on the ex-dividend date and the stock price on this date does not drop by the full amount of dividend. Moreover, trend of stock return which is positive before the ex-dividend date and negative afterwards supports the short-term trading hypothesis. Recently, Dharmarathne (2013) revealed that the stock price positively reacts to dividend announcements. Particularly, dividend increase announcements support the information content of dividend hypothesis. However, dividend decrease announcements and dividend no change announcements against with the information content of dividend hypothesis. Menike (2014) investigated the stock price reactions to the dividend announcement and he determined information content of dividend announcement. Based on this, the market positively responses to the dividend announcement on the event date.

In Vietnam, a few studies have been also conducted to investigate the impact of dividend policy on stock price. 
Vinh (2014) examined the impact of dividend policy which is measured by payout ratio and dividend yield on stock price volatility. By using panel data and regression models to analyze a sample consisting of 103 listed firms in Vietnam from 2008 to 2012, he presented a statistically significant correlation between dividend policy and stock price volatility. After that, Vinh (2015) applied the event study methodology to study the market reaction to cash dividend announcement. This research was conducted based on a sample comprising non-financial companies listed on Vietnamese stock market in the period of 2008-2014 and the results were inconsistent to the semi-strong form of efficient market hypothesis (Fama, 1970). Indeed, he showed that as soon as the information of dividend policy is available to the public market tended to respond slowly in terms of price but quickly in terms of trading volume. More recently, Trung and Dat (2015) also used the traditional event study methodology to investigate the effect of dividend announcement on stock price in Vietnamese stock market. They chose a sample including 979 dividend events of 233 listed companies in the period of 2008-2014 for this research. These authors found that the stock market react positively to share prices and trading volume around the dividend announcement day.

\section{Data and Methodology}

The aim of the study is to analyse the impact of dividend announcement on the stock return. In order to achieve this goal, the market reaction to the announcements of dividend is carefully investigated.

In this research, the event study methodology, which was developed by Bowman (1983), Brown and Warner (1980, 1985), Fama (1991) and MacKinlay (1997), is applied to measure abnormal returns of the shares around the time that news related to dividend events becomes publicly available. This method allows us to determine the relation between the dividend policy and the stock value. The abnormal returns are estimated over the event windows for each transaction. In the dividend policy study, two important dates consisting of the dividend announcement date and the ex-dividend date are considered. Here, the ex-dividend date is used as an event date because of the difficulty in collecting actual dividend announcement date, i.e., declaration date in Vietnam. Normally, the dividend announcement date is determined between day 8 to day 15 before the ex-dividend date. We have searched and collected data from two websites (www.cophieu68.vn and fpts.com.vn) to determine the ex-dividend date.

A sample including 1962 observations of dividend-related events from 432 listed companies in Vietnam during the period 2008 to 2015 is used for this study. Based on the financial reports of the listed companies in Vietnam stock market, we obtain the daily stock price of target firms to calculate the stock return. The price index (VN-index) is also used to calculate the market return.

The following steps are taken for implementing the event study:

\section{- Identification of the event window}

We examine different sub event windows $[\mathrm{t}-10, \mathrm{t}+10]$, $[\mathrm{t}-3, \mathrm{t}+3]$, $[\mathrm{t}-2, \mathrm{t}+2],[\mathrm{t}-1, \mathrm{t}+1] \ldots$ over the main period $[\mathrm{t}-20, \mathrm{t}+20]$ with $\mathrm{t}=0$ representing the time of the event.

- Determination of a expected return of the security i for time $t$ during the event window in the absence of the event (Kit)

We use a simple market model to estimate coefficient $\alpha$ and $\beta$ of firms basing on the return data of 130 dates prior to the event window $\left(\mathrm{t}_{-150,}, \mathrm{t}_{-21}\right)$ :

$$
R_{i t}=\alpha_{i}+\beta_{i} R_{M t}+\varepsilon_{i t} \quad t € I_{N}
$$

For each event, the market model is estimated over the period 150 to 21 trading dates prior to the event date.

Then, the expected return $\mathrm{K}_{\mathrm{it}}$ is estimated for time $\mathrm{t}$ during the event window:

$$
K_{i t}=\alpha_{i}+\beta_{i} R_{M t} \quad t \in I
$$

\section{- $\quad$ Calculation of the abnormal return within the event window}

We calculate the abnormal returns by differencing the observed return $\mathrm{R}_{\mathrm{it}}$ and the expected return $\mathrm{K}_{\mathrm{it}}$ : AR

$$
A R_{i t}=R_{i t}-K_{i t}
$$

\section{- $\quad$ Calculation of the average abnormal return (AAR) and the cumulative average abnormal return (CAAR)}

Given N events (a total of 1962 in the entire sample), the sample average aggregated abnormal return for period $t$ is:

$$
\operatorname{AAR}_{\mathrm{t}}=\frac{1}{\mathrm{~N}} \sum_{\mathrm{i}=1}^{\mathrm{N}} \mathrm{AR}_{\mathrm{it}}
$$


The average abnormal return can then be aggregated over the event window to calculate the cumulative average abnormal return for each firm i:

$$
\operatorname{CAAR}_{t 1, t 2}=\sum_{t=t_{1}}^{t 2} A A R_{t}
$$

- $\quad$ Testing whether the abnormal return is statistically different from 0

We formulate the testable hypothesis: "The average abnormal return is zero".

$$
\mathrm{H}_{0}: \mathrm{E}\left(\mathrm{AAR}_{\mathrm{t}}\right)=0
$$

We use Student's t-test to test whether the average abnormal return and the cumulative average abnormal return are statistically different from 0 .

$$
T=\frac{A A R_{t}}{\sigma_{\text {AAR }_{t}}} \text { and } T^{\prime}=\frac{C A A R_{t 1, t 2}}{\sigma_{C A A R_{t 2}}}
$$

where the standard deviation of AAR is determined by Christie (1983) and is given by:

$$
\begin{gathered}
\sigma_{A A R_{t}}=\frac{1}{\sqrt{N}} \sqrt{\frac{1}{N-1} \sum_{i=1}^{N}\left(A R_{i t}-A A R_{t}\right)^{2}} \\
\sigma_{C A A R_{t 2}}=(\sqrt{t 2-t 1+1}) \sigma_{A A R_{t 2}}
\end{gathered}
$$

\begin{tabular}{|c|c|c|c|c|}
\hline Date & $A A R(\%)$ & CAAR (\%) & $t$-test $A A R$ & Prob. \\
\hline-20 & 0.00018 & 0.00018 & 0.2677 & 0.7889 \\
\hline-19 & 0.00097 & 0.00115 & 1.4153 & 0.1570 \\
\hline-18 & 0.00095 & 0.00125 & 0.1356 & 0.8922 \\
\hline-17 & 0.00028 & 0.00153 & 0.3984 & 0.6903 \\
\hline-16 & $0^{0.00138}{ }^{* *}$ & 0.00290 & 2.0089 & 0.0453 \\
\hline-15 & 0.00091 & 0.00381 & 1.3439 & 0.1790 \\
\hline-14 & $0.00144^{* *}$ & 0.00525 & 2.0666 & 0.0388 \\
\hline-13 & 0.00112 & 0.00637 & 1.5267 & 0.1268 \\
\hline-12 & $0.00249^{* * * *}$ & 0.00885 & 3.5481 & 0.0004 \\
\hline-11 & $0.00254^{* * *}$ & 0.01139 & 3.5345 & 0.0004 \\
\hline-10 & $0.00229^{* * * *}$ & 0.01367 & 3.1516 & 0.0016 \\
\hline-9 & $0.00274^{* * *}$ & 0.01641 & 2.9579 & 0.0031 \\
\hline-8 & $0.00460^{* * *}$ & 0.02101 & 6.0757 & 0.0000 \\
\hline-7 & $0.00458^{* * * *}$ & 0.02559 & 6.3030 & 0.0000 \\
\hline-6 & $0.005799^{* * *}$ & 0.03138 & 7.6532 & 0.0000 \\
\hline-5 & $0.00305^{* * *}$ & 0.03144 & 4.2314 & 0.0000 \\
\hline-4 & $0.00254^{* * *}$ & 0.03697 & 3.5214 & 0.0000 \\
\hline-3 & $0.00099^{* * *}$ & 0.03797 & 1.3811 & 0.0004 \\
\hline-2 & 0.00056 & 0.03853 & 0.7755 & 0.1672 \\
\hline-1 & $-0.00408^{* * * *}$ & 0.03445 & -5.6583 & 0.0000 \\
\hline 0 & $-0.07247^{* * *}$ & $-\mathbf{0 . 0 3 7 0 3}$ & -100.53 & 0.0000 \\
\hline 1 & -0.00107 & -0.03910 & -1.4840 & 0.1378 \\
\hline 2 & $-0.00617^{* * *}$ & -0.04526 & -8.5520 & 0.0000 \\
\hline 3 & $-0.00471^{* * * *}$ & -0.04997 & -6.5317 & 0.0000 \\
\hline 4 & $-0.00168^{* *}$ & -0.05165 & -2.3367 & 0.0195 \\
\hline 5 & -0.00127 & -0.05293 & -1.7651 & 0.7776 \\
\hline
\end{tabular}

\section{Empirical Results}

Table below presents the average abnormal returns for the event window $(-20,5)$.

Table 1. Average abnormal return and the student's t-test

***** ${ }^{*}$ and ${ }^{*}$ represent significance at the $1 \%, 5 \%$ and $10 \%$. 
We find that at the particular dates $t=-1$ and $t=0$, the AAR is significantly negative $\left(\mathrm{AAR}_{\mathrm{t}=-1}=-0.41 \%\right.$ and $\left.\mathrm{AAR}_{\mathrm{t}=0}=-7.25 \%\right)$ and the null hypothesis $\mathrm{H}_{0}$ is rejected at $1 \%$ level of significance. This means that at the event date (ex-dividend date), the average abnormal return is strongly negative for the firms whose shares are purchased and the market reacts earlier than the actual announcement of ex-dividend.

During the post announcement period $(\mathrm{t}=+1$ to $\mathrm{t}=+5)$, the AAR and the CAAR of these dates are negative. The AAR on the dates 2, 3 and 4 is statistically significant at $1 \%$ and $5 \%$ levels. However, before the ex-dividend date $(t=-20$ to $t=-2)$, all the AAR and the CAAR are positive. More specifically, the AAR from the date -12 to the date -2 is statistically significant at 1 percent levels and the AAR on the dates -16 and -14 is statistically significant at 5 percent levels. This indicates that the market reacts around the ex-dividend date as follows: before the ex-dividend date, the stock price increases and decreases afterwards since the ex-dividend date which determines a person to be awarded the dividend is the most important date in dividend investing. Our results are in good agreement with a point of view that a company's share price may go up as the ex dividend date approaches and then go down after the ex dividend date.

The positive AAR over a window period starting from date -20 to date -5 relative to the ex-dividend date (0-date) also implies that the impact of the dividend announcement on the stock return is positive. Normally, the dividend announcement date (declaration date) is determined between day 8 to day 15 before the ex-dividend date. The AAR in this period is positive and statistically significant at $5 \%$ or $1 \%$ levels. This result shows that the announcement of dividend payment coincides with the remarkable changes of firm values. As seen, the relation between the stocks return and the dividend announcement is also positive and this confirms that the dividend announcement of the listed firms in Vietnam conveys positive information to market participants.

Table 2 reports the cumulative average abnormal returns for different event windows over the period of dividend declaration. Based on this table, the dividend announcement generates remarkably positive CAAR during a few trading dates before and after the announcement of dividend payment. The average cumulative abnormal returns of the subwindows $(-20,-1),(-20,-5),(-15,-5)$ etc. around the dividend announcement date are positive and statistically significant at $1 \%$ level. In other words, impact of dividend announcement on the performance of companies is strongly positive around the announcement date. It is useful to recall that according to the dividend signaling theory, a company decides to announce its dividend payout policy to signal its future prospects to the market, leading to a change of its stock prices. Our results show that the market reacts favorably to the announcements of dividend policy of the companies listed on the Vietnamese stock market. This result which is also consistent with the previous studies, e.g., Scott and Keith (1996), Aharony and Swary (1980) and Dharmarathne (2013), supports the information content of dividend hypothesis.

Table 2. Cumulative average abnormal return and the student's t-test around the announcement dividend date

\begin{tabular}{lllll}
\hline & Event windows & CAAR $(\%)$ & $t$-test - CAAR & Prob. \\
\hline Main window & $(-20,20)$ & $-0.0563^{* * *}$ & -12.1872 & 0.0000 \\
& $(-20,-10)$ & $0.0137^{* * *}$ & 5.7182 & 0.0000 \\
& $(-20,-5)$ & $0.0344^{* * *}$ & 11.9409 & 0.0000 \\
Sub windows & $(-20,-1)$ & $0.0349^{* * *}$ & 10.6846 & 0.0000 \\
& $(-15,-5)$ & $0.0315^{* * *}$ & 13.1876 & 0.0000 \\
& $(-15,-1)$ & $0.0316^{* * *}$ & 11.2982 & 0.0000 \\
\hline
\end{tabular}

${ }_{* * * * * *}^{* *}$ and ${ }^{*}$ represent significance at the $1 \%, 5 \%$ and $10 \%$.

Cumulative average abnormal return for different event windows around the ex-dividend date is also reported in Table 3.

Table 3. Cumulative average abnormal return and the student's t-test around the ex-dividend date

\begin{tabular}{lllll}
\hline & Event windows & CAAR $(\%)$ & $t$-test - CAAR & Prob. \\
\hline Main window & $(-20,20)^{* * *}$ & -0.0563 & -12.1872 & 0.0000 \\
& $(-10,10)^{* * *}$ & -0.0682 & -20.6332 & 0.0000 \\
& $(-5,5)^{* * *}$ & -0.0843 & -35.2617 & 0.0000 \\
& $(-5,-1)^{*}$ & 0.0031 & 1.9012 & 0.0573 \\
\hline
\end{tabular}




\begin{tabular}{|c|c|c|c|c|}
\hline \multirow[t]{4}{*}{ Sub windows } & $(-3,3)^{* * *}$ & -0.0869 & -45.5829 & 0.0000 \\
\hline & $(-3,1)^{* * *}$ & -0.0761 & -47.1888 & 0.0000 \\
\hline & $(-2,2)^{* * *}$ & -0.0832 & -51.6310 & 0.0000 \\
\hline & $(-1,1)^{* * * *}$ & -0.0776 & -62.1655 & 0.0000 \\
\hline
\end{tabular}

${ }^{* * * * * *}$ and ${ }^{*}$ represent significance at the $1 \%, 5 \%$ and $10 \%$.

The reaction of stock prices on the ex-dividend date is also clearly revealed. The CAAR of all sub windows including the date after the ex-dividend date is negative and statistically significant at the $1 \%$. However, the CAAR for a $(-5,-1)$ window before the ex-dividend date is positive and statistically significant at the $10 \%$. This proves that the dividend payment has a strongly immediate impact on the share price of the Vietnamese stock market. A fall in stock price can be seen from the ex-dividend date onward because the dividend payment possesses a signaling effect. Our results in which the trend of stock return is positive before the ex-dividend date but negative afterwards are in good agreement with the short-term trading hypothesis. This result implies buying pressure on the part of short-term traders in the pre-ex-date period and selling pressure in the post-ex-date period. However, our results are not consistent with some previous studies. Indeed, Romon (2000) doubted about the dividend clientele hypothesis when examining the stock price reactions at the ex-dividend date. This author claimed that the dividend clientele effect seems to be extremely limited because the market knows the firm dividend policy level before the ex-dividend dates. In addition, Dasilas (2007) analyzed the ex-dividend stock price and found that the stock price does not drop on this date. However, based on our result which is shown in Figure 1, a strong decline of the ex-dividend stock price is clearly revealed.

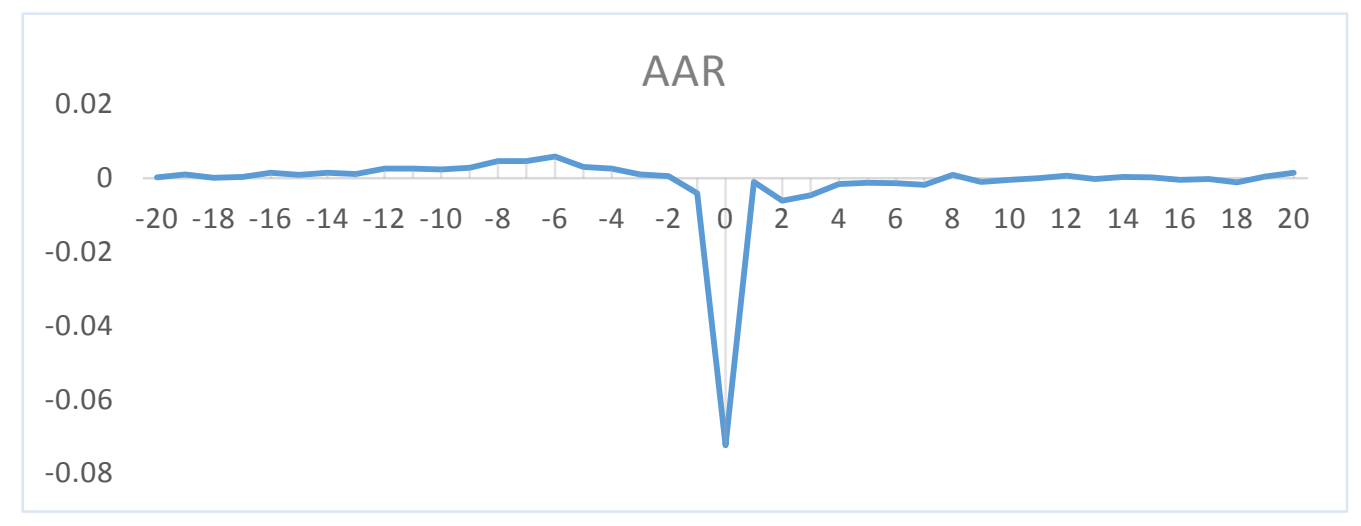

Figure 1. Average abnormal return (\%)

Measurement of CAAR over the period $(t-20, t+20)$ are shown below.

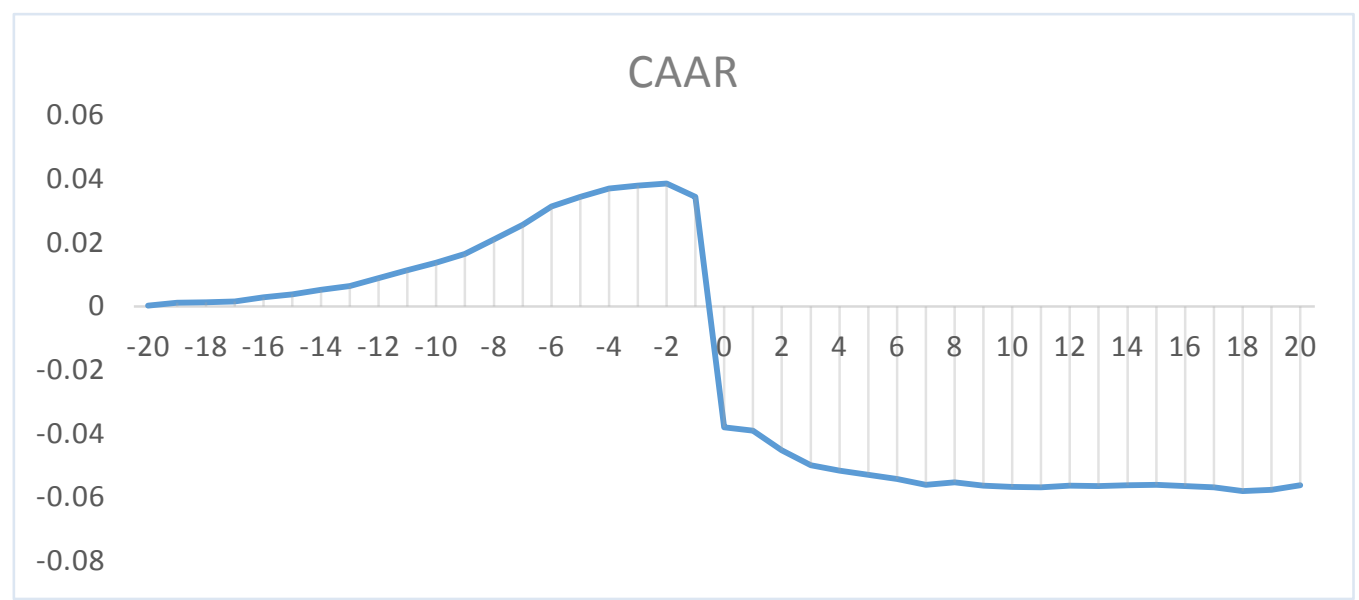

Figure 2. Cumulative average abnormal return (\%) 
As shown above, CAAR values which are measured before and after the ex-dividend date are completely different. Indeed, CAAR is positive and exhibits a gradually increase from day 20 before the ex-dividend date. On the other hand, from the ex-dividend date onward, CAAR is negative and keeps decreasing. More importantly, CAAR appears to be positive around the dividend announcement date which is normally determined between day 8 to day 15 before the ex-dividend date $(t=0)$. This indicates that the stock price of the firms listed in the Vietnamese stock exchange reacts positively to the dividend announcement.

\section{Conclusion}

In this research, by examining the stock returns subsequent to the dividend announcements, we have verified whether the dividend policy influences the firm value in the context of Vietnam. It is clear that our results have supported the dividend relevance theory in which the dividend policy affects the firm value. Particularly, the effect of dividend announcement on the stock return of the companies is positive around the announcement date. We have also found that the stock price increases as long as the ex-dividend date approaches but starts decreasing afterwards. Our findings would enhance current understandings of the dividend policy impact on the firm value and that allows financial managers to be able to determine an optimal dividend policy which improve the performance of the firms.

\section{References}

Adefila, J. J., Oladipo, J. A., \& Adeoti, J. O. (2004). The Effect of Dividend Policy on the Market Price of Shares in Nigeria: Case Study of Fifteen Quoted Companies. International Journal of Accounting, 2(1). Retrieved from http://www.iosrjournals.org/iosr-jef/papers/Vol5-Issue4/G0544962.pdf

Akerlof, G. A. (1970). The Market for "Lemons": Quality Uncertainty and the Market Mechanism. Quarterly Journal of Economics, 84(3), 488-500. http://dx.doi.org/10.2307/1879431

Allen, F., Antonio, E. B., \& Ivo, W. (2000). A Theory of Dividends Based on Tax Clienteles. Journal of Finance, 55, 2499-2536. http://dx.doi.org/10.1111/0022-1082.00298

Baker, H. K., \& Powel, G. E. (1999). How corporate managers view dividend policy. Quarterly Journal of Business and Economics, 38(2), 17-35. Retrieved from http://www.jstor.org/stable/40473257

Baker, H. K., Powel, G. E., \& Vei, E. T. (2002). Revisiting Managerial Perspectives on Dividend Policy. Journal of Economics and Finance, 26(3), 267-283. http://dx.doi.org/10.1007/BF02759711

Baskin, J. (1989). Dividend policy and the volatility of common stocks. The Journal of Porfolio Management, 15(3), 19-25. http://dx.doi.org/10.3905/jpm.1989.409203

Bhattacherya, S. (1979). Imperfect information, Dividend Policy, and "The Bird in the Hand" Fallacy. The Bell Journal of Economics, 10(1), 259-270. http://dx.doi.org/10.2469/dig.v27.n1.3

Black, F., \& Scholes, M. (1974). The effects of dividend yield and dividend policy on common stock prices and returns. Hournal of Financial Economics, 1(1), 1-22. http://dx.doi.org/10.1016/0304-405X(74)90006-3

Bowman, R. G. (1983). Understanding and Conducting Event Studies. Journal of Business Finance and Accounting, 10(4), 561-584. http://dx.doi.org/10.1111/j.1468-5957.1983.tb00453.x

Brown, S. J., \& Warner, J. B. (1985). Using Daily Stock Returns: The Case of Event Studies. Journal of Financial Economics, 14(1), 3-31. http://dx.doi.org/10.1016/0304-405X(85)90042-X

Gong-meng, C., Michael, F., \& Ning, D. G. (2002). The Information Content of Concurrently Announced Earnings, Cash Dividends, and Stock Dividends: An Investigation of the Chinese Stock Market. Journal of International Financial Management and Accounting, 13(2), 101-124. http://dx.doi.org/10.1111/1467-646X.00080

Dharmarathne, D. G. (2013). Stock price reaction to dividend announcements and information efficiency in Sri Lankan share market. International Journal of Research in Social Sciences, 3(2), 100-111. Retrieved from http://www.iiste.org/Journals/index.php/EJBM/article/download/12525/12832

Dong, M., Robinson, C. A., \& Veld, C. (2005). Why Individual Investors Want Dividends. Journal of Corporate Finance, 1(12), 121-158. http://dx.doi.org/10.1016/j.jcorpfin.2004.04.006

Fama, E. F., \& French, K. R. (1988). Dividend Yield and Expected Stock Returns. The Journal of Financial Economics, 22(1), 3-25. http://dx.doi.org/10.1016/0304-405X(88)90020-7

Friend, L., \& Puckett, M. (1964). Dividends and Stock Prices. The American Economic Review, 54(5), 656-682.

Gordon, M. J. (1963). Optimal investment and financing policy. Journal of Finance, 18(2), 264-72. 
http://dx.doi.org/10.1111/j.1540-6261.1963.tb00722.x

Habib, Y., Kiani, Z. I., \& Khan, M. A. (2012). Dividend Policy and Share Price Volatility: Evidence from Pakistan. Global Journal of Management and Business Research, 12(5). Retrieved from https://globaljournals.org/GJMBR_Volume12/9-Dividend-Policy-and-Share-Price-Volatility.pdf

Hussainey, K., Mgbame, C. O., \& Chijoke-Mgbame, A. M. (2011). Dividend policy and share price volatility: UK evidence. The Journal of Risk Finance, 12(1), 57-68. http://dx.doi.org/10.1108/15265941111100076

John, K., \& Joseph, W. (1985). Dividends, Dilution, and Taxes: A Signaling Equilibrium. Journal of Finance, 40, 1053-107. http://dx.doi.org/10.2307/2328394

Khan, K. I. (2012). Effect of Dividends on Stock Prices - A case of chemical and pharmaceutical Industry of Pakistan. Journal of Management, 2(5), 141-148. http://dx.doi.org/10.5923/j.mm.20120205.02

Lintner, J. V. (1956). Distribution of Incomes of Corporations among Dividends, Retained Earnings, and Taxes. American Economic Review, XXXXVI(2), 97-133. Retrieved from http://www.jstor.org/stable/1910664

Mac Kinlay, A. C. (1997). Event studies in economics and finance. Journal of Economic Literature, 35, 13-39. Retrieved from http://www.e-jel.org/archive/mar1997/Mackinla.pdf

Maditinos, D. I., Sevic, Z., Theriou, N. G., \& Tsinani, A. V. (2007). Individual Investors'Perceptions Towards Dividends: The Case of Greece. International Journal of Monetary Economics and Finance, 1(1), 18-31. http://dx.doi.org/10.1504/IJMEF.2007.016023

Menike, M. G. P. D. (2014). Stock Price Reactions to the Dividend Announcement in the Emerging Market: Case in the Colombo Stock Exchange Sri Lanka. European Journal of Business and Managemen, 6(12). Retrieved from http://www.iiste.org/Journals/index.php/EJBM/article/download/12525/12832

Miller, M. H., \& Modigliani, F. (1961). Dividend policy, growth, and the valuation of shares. Journal of Business, 34(4), 411-433. http://dx.doi.org/10.1086/294442

Miller, M. H., \& Kevin, R. (1985). Dividend policy under asymmetric information. Journal of Finance, 40, 1031-1051. http://dx.doi.org/10.1111/j.1540-6261.1985.tb02362.x

Myers, M., \& Frank, B. (2004). The Determinants of Corporate Dividend Policy. Academy of Accounting and Financial Studies Journal, 8(3), 17-28. $\quad$ Retrieved from http://www.slideshare.net/AlexanderDecker/the-determinants-of-corporate-dividend-policy-an-investigation -of-pakistani-banking-industry

Nazir, M. S., Nawaz, M. M., Anwar, W., \& Ahmed, F. (2010). Determinants of Stock Price Volatility in Karachi Stock Exchange: The Mediating Role of Corporate Dividend Policy. International Research Journal of Finance and Economics, 55, 100-107. Retrieved from http://www.ciitlahore.edu.pk/Papers/Abstracts/146-8589069429892551798.pdf

Nishat, M., \& Irfan, C. M. (2003). Dividend Policy and Stock Price Volatility in Pakistan. 11th Pacific Basin Finance, Economics and Accounting Conference. Retrieved from http://www.ijsrp.org/research-paper-0215/ijsrp-p3848.pdf

Ohlson, J. A. (1995). Earnings, Book Values, and Dividends in Equity Valuation. Contemporary Accounting Research, 11(2), 661-687. http://dx.doi.org/10.1111/j.1911-3846.1995.tb00461.x

Rashid, A., \& Rahman, A. Z. M. A. (2008). Dividend policy and stock price volatility: Evidence from Bangladesh. Journal of Applied Business and Economics, 8(4), 71-81. Retrieved from http://www.na-businesspress.com/JABE/RashidWeb.pdf

Romon, F. (2000). Contribution of Dividend Policy Stability to the Measurement of Dividend Announcement and Ex-Dividend Policy Effects on the French Market. WP EFMA Athens. http://dx.doi.org/10.2139/ssrn.234149

Scott, D. B., \& Keith, H. J. (1996). An analysis of shareholder reaction to dividend announcements in bull and bear markets. Journal of Financial and Strategic Decisions, 9(3), 15-26. Retrieved from http://www.studyfinance.com/jfsd/pdffiles/v9n3/below.pdf

Travlos, N., Lenos, T., \& Nikos, V. (2001). Shareholder Wealth Effects of Dividend Policy Changes in an Emerging Stock Market: The Case of Cyprus. Multinational Finance Journal, 5(2), 87-112. http://dx.doi.org/10.17578/5-2-1

Trung, T. Q., \& Dat, M. Y. (2015). Stock market Reaction to Dividend Announcements from a Special 
Institutional Environment of Vietnamese Stock Market. International Journal of Economics and Finance, 7(9), 50-58. http://dx.doi.org/10.5539/ijef.v7n9p50

Uddin, H. M., \& Golam, M. C. (2005). Effects of Dividend Announcement on Shareholders' Value: Evidence from Dhaka Stock Exchange. Journal of Business Research, 7, 61-72. Retrieved from http://www.iiste.org/Journals/index.php/RJFA/article/viewFile/1307/1227

Vinh, V. X. (2014). Dividend Policy and Stock Price Volatility in Vietnam stock market. Journal of Economics \& Development, 203, 48-55.

Vinh, V. X. (2015). Stock market reaction to dividend announcement - Empirical evidence from Vietnam. Journal of Economics \& Development, 219, 55-65.

Zkaria, Z., Muhamad, J., \& Zukifili, A. H. (2012). The impact of dividend policy on the share price volatility: Malaysian Construction and Material Companies. International Journal of Economics and Management Sciences, $2(5), \quad 1-8 . \quad$ Retrieved from http://www.iiste.org/Journals/index.php/EJBM/article/download/12215/12568

\section{Copyrights}

Copyright for this article is retained by the author(s), with first publication rights granted to the journal.

This is an open-access article distributed under the terms and conditions of the Creative Commons Attribution license (http://creativecommons.org/licenses/by/3.0/). 